\title{
ANALISIS KESALAHAN PESERTA DIDIK DALAM MENYELESAIKAN SOAL MATEMATIKA TRANSFORMASI GEOMETRI KELAS IX
}

\section{(ANALYSIS OF STUDENT'S ERRORS IN SOLVING WORD MATHEMATICS OF GEOMETRY TRANSFORMATION IN IX GRADE)}

\author{
Hanifah Zahra 'Ashri', Indrie Noor Aini' \\ ${ }^{1}$ Universitas Singaperbangsa Karawang, hanifahzahra36@gmail.com \\ ${ }^{2}$ Universitas Singaperbangsa Karawang, indrie.nooraini@staff.unsika.ac.id
}

\begin{abstract}
Abstrak
Penelitian ini bertujuan untuk mendeskripsikan kesalahan peserta didik dalam menyelesaikan soal matematika pada materi transformasi geometri kelas IX dengan teori Newman. Subjek dalam penelitian ini dipilih dengan menggunakan purposive sampling menimbang kemampuan pemecahan masalah matematis peserta didik dengan inisial S1 untuk kategori tinggi, S2 untuk kategori sedang dan S3 untuk kategori rendah. Teknik pengumpulan data yang digunakan adalah dengan tes tertulis berbentuk soal cerita. Hasil penelitian menunjukkan bahwa pada kesalahan dalam keterampilan proses terlihat dominan dibandingkan kesalahan yang lain. Secara umum hal itu disebabkan karena peserta didik masih belum bisa melanjutkan prosedur solusi pemecahan masalah untuk menyelesaikan soal dengan baik dan banyaknya ketidaktelitian peserta didik pada proses perhitungan. Selain itu juga terdapat hubungan antara kemampuan pemecahan masalah matematis dengan kesalahan yang terlihat oleh peserta didik dalam menyelesaikan soal menurut teori Newman..
\end{abstract}

Kata kunci: Analisis Kesalahan, Soal Matematika, Transformasi Geometri

\begin{abstract}
This study aimed to describe the student's errors in solving mathematics question of geometry transformation in IX grade with Newman's theory. The Subjects in this study were chosen with purposive sampling using problem solving abilities student's in initial S1 for high category, S2 for medium category, and S3 for low category. The researches used written test in the form of story problems as data collection. The result showed that in progress skill's errors seem dominant than another one. In generally it is caused student can't continue the solution's procedure in problem solving to finish the question well and mostly students are not being careful in counting progress. In addition, there is a correlation between problem solving abilities in mathematics with student's errors to finish the questions according to Newman's theory.
\end{abstract}

Keywords: Error Analysis, Math Word, Geometry Transformation

\section{PENDAHULUAN}

Pada saat ini, pembelajaran yang digunakan di Indonesia adalah kurikulum 2013 (kurtilas) edisi revisi tahun 2017 yang sudah tidak lagi berpusat pada guru 
dimana guru hanya memberikan materi di papan tulis dan peserta didik memperhatikan dan mengerjakan saja soal yang diberikan, namun sudah berpusat pada peserta didik dimana peserta didik juga harus berperan aktif dalam kegiatan pembelajaran seperti peserta didik sudah dapat mencari tahu dasar pembelajarannya sendiri dan mampu mengkontruksi sendiri pemahamannya dari apa yang guru berikan secara mandiri karena peran guru saat ini hanya sebagai fasilitator dalam kegiatan pembelajaran namun tetap dilihat, dievaluasi, diperbaiki bahkan ditingkatkan proses dan hasil belajar peserta didik agar kesalahan dan kesulitan belajar yang terjadi dapat dianalisis dan kemudian diberikan solusi sehingga tujuan pembelajaran tercapai dengan baik dan terdapat perubahan perilaku serta prestasi belajar matematika peserta didik (Layn \& Kahar, 2017).

Pada pembelajaran matematika tidak menutup kemungkinan bahwa masih banyak peserta didik yang masih melakukan kesalahan dalam menyelesaikan soal matematika. Kesalahan yang sering terjadi dilakukan peserta didik adalah kesalahan konsep, operasi, fakta dan prinsip terutama ketika peserta didik disajikan permasalahan dalam bentuk soal cerita. Peserta didik memiliki kesulitan jika bilangan yang digunakan berhubungan dengan pengukuran (seperti $9 \mathrm{~cm}, 10$ gr, 15 liter dan lain sebagainya) dibandingkan dengan unit diskrit (seperti 9 baju, 10 apel, 17 mobil dan lain sebagainya). Jika pada soal cerita terdapat bilangan desimal, peserta didik merasa lebih sulit untuk menentukkan operasi matematika dalam menyelesaikan soal tersebut sehigga peserta didik sering menghindari membaca soal cerita hingga tuntas dan langsung mencoba menyelesaikan soal hanya berfokus pada bilangannya saja (Karnasih, 2015).

Brown \& Skow (2016) mengatakan bahwa dengan menganalisis kesalahan peserta didik dalam menyelesaikan soal sudah terbukti menjadi salah satu solusi yang efektif untuk mengetahui pola kesalahan peserta didik. Berdasarkan pendapat tersebut bahwa analisis kesalahan sangatlah penting dan perlu dikembangkan agar para guru dapat mengetahui kesalahan yang sering dilakukan oleh peserta didik dan menjadi bahan evaluasi para guru untuk dapat menciptakan proses belajar mengajar yang lebih baik dan dapat menentukan strategi yang tepat agar pemahaman peserta didik mengenai materi semakin kuat dan tidak terjadi lagi kesalahan di kemudian hari (Rahmania \& Rahmawati, 2016).

Salah satu analisis kesalahan yang dapat digunakan adalah teori Newman. Teori Newman didesain sebagai prosedur yang sederhana dalam menyelesaikan soal cerita matematis. Selain itu ternyata teori Newman juga dapat diterapkan dalam proses kegiatan pembelajaran maupun proses evaluasi yang disebut dengan penerapan NEA (Newman's Error Analysis) dan berhubungan dengan kemampuan pemecahan masalah matematis peserta didik (Karnasih, 2015).

Berdasarkan uraian diatas, hal itu membuat peneliti tertarik untuk melakukan penelitian dengan menganalisis hasil jawaban peserta didik dalam menyelesaikan soal pada materi Transformasi Geometri di kelas IX untuk mengetahui letak kesalahan peserta didik dengan menggunakan teori Newman. Namun pada penelitian ini dibatasi hanya menggunakan 3 tahapan saja yaitu (1) mengumpulkan data kesalahan; (2) mengklarifikasi dan mengidentifikasi kesalahan; dan (3) mengoreksi kesalahan. Penelitian ini bertujuan untuk mendeskripsikan kesalahan yang dilakukan subjek penelitian dalam menyelesaikan soal yang diberikan peneliti mengenai materi Transformasi Geometri dengan teori Newman. 


\section{KAJIAN TEORI}

NEA (Newman's Error Analysis) pada awalnya dipromosikan oleh Clements pada sekitar tahun 1980-an. Kemudian Clements bekerja sama dengan Ellerton di Australia. NEA dikembangkan untuk membantu para pengajar jika berhadapan dengan peserta didik yang mengalami kesulitan dalam menyelesaikan permasalahan dalam bentuk soal cerita. NEA memberikan peserta didik pengalaman yang berorientasi pada latihan dan praktek dengan harapan bahwa peserta didik mampu memperbaiki kesalahan-kesalahan mereka dalam menyelesaikan permasalahan dalam bentuk soal cerita. NEA menyediakan kerangka yang mampu menemukan alasan yang menyebabkan kesulitan pada proses pembelajaran peserta didik dan mampu membantu para pengajar untuk bisa menemukan dimana titik kesalahan peserta didik dan mampu memberikan solusi dengan menentukan strategi pembelajaran yang efektif agar kesalahan tersebut tidak terulang kembali (Karnasih, 2015).

Newman (1977) mengatakan bahwa ketika peserta didik akan menyelesaikan soal berbentuk soal cerita maka langkah-langkah yang harus dilalui adalah membaca masalah dari soal tersebut, memahami apa yang dibaca, melakukan transformasi (mengubah) dari kata-kata dalam masalah kedalam pemilihan solusi matematis yang tepat, mengaplikasikan keterampilan proses dan strategi yang ditentukan dan memberikan kode jawaban kedalam bentuk tulisan yang bisa diterima (Karnasih, 2015).

Dalam setiap langkah-langkah itu tidak menutup kemungkinan bahwa peserta didik bisa terjadi kecerobohan dan kesalahan yang mengakibatkan peserta didik tidak dapat menjawab soal tersebut dengan baik. Hasil dari penelitian Newman (2008) menjelaskan bahwa peserta didik mengalami kesulitan pada struktur semantik, kata kalimat dan simbol matematika jika dibandingkan dengan algoritma standar (Karnasih, 2015). Misalkan pada langkah membaca, jika peserta didik tidak mampu membaca simbol dalam permasalahan yang tertulis akan mencegah peserta didik untuk dapat melakukan proses selanjutnya yang sesuai dengan langkah pemecahan masalah. Kemudian pada langkah memahami, misalkan siswa sudah bisa membaca semua kalimat dalam masalah namun tidak memahami apa yang dimaksud dari permasalahan yang diberikan maka peserta didik tidak bisa melangkah lebih jauh karena peserta didik gagal untuk mendapatkan apa yang dibutuhkannya. Pada langkah transformasi, misalkan peserta didik mampu memahami permasalahan yang diberikan namun peserta didik tidak bisa memilih rencana solusi yang diperlukan maka peserta didik gagal untuk menyelesaikan masalah tersebut dengan tepat. Pada langkah keterampilan proses, misalkan peserta didik sudah mampu memlih rencana solusi dengan tepat namun tidak mengetahui prosedur yang diperlukan untuk melaksanakan rencana solusi tersebut maka peserta didik akan berhenti pada penulisan rumus yang digunakan tanpa melanjutkannya. Pada langkah penulisan, misalkan peserta didik sudah berhasil memecahkan permasalahan yang diberikan dengan baik namun peserta didik masih terdapat kesalahan dalam menuliskan apa yang dimaksudnya maka kesalahan itu juga akan berdampak pada kesimpulan jawaban.

Pada Teori Newman dapat dibedakan dalam lima tipe kesalahan dalam mengerjakan soal matematika, yaitu (1) kesalahan dalam membaca, hal itu dapat terjadi dikarenakan peserta didik tidak membaca soal dengan baik sehingga informasi dasar dalam soal tidak peserta didik pahami sehingga jawaban yang 
peserta didik berikan tidak tepat dengan apa yang dimaksud dalam soal; (2) kesalahan dalam memahami, hal itu dapat terjadi dikarenakan peserta didik belum bisa memahami konsep soal dengan baik sehingga peserta didik tidak tahu apa saja yang ditanyakan dalam soal dan tidak paham mengenai informasi yang ada sehingga peserta didik tidak dapat menyelesaikan permasalahan tersebut; (3) kesalahan dalam transformasi (mengubah), hal itu dapat terjadi karena peserta didik belum bisa mengubah soal kedalam bentuk matematika yang benar sehingga peserta didik salah menggunakan operasi hitung dalam menyelesaikan soal; (4) kesalahan dalam keterampilan proses, hal itu dapat terjadi karena peserta didik belum terampil dalam mengolah perhitungan dengan baik; (5) kesalahan pada notasi, hal itu terjadi pada proses penyelesaian soal oleh peserta didik (Mahmudah, 2018).

Dari setiap tipe kesalahan pada langkah-langkah diatas, Newman menentukan indikator dari setiap kesalahan langkah kedalam bentuk sebagai berikut :

Tabel 1. Pedoman Kategori Tipe Kesalahan (Mahmudah, 2018)

\begin{tabular}{|c|c|c|}
\hline No & $\begin{array}{l}\text { Kategori Kesalahan } \\
\text { Teori Newman }\end{array}$ & Indikator Kesalahan \\
\hline 1. & $\begin{array}{ll}\text { Kesalahan } & \text { dalam } \\
\text { Membaca } & \end{array}$ & $\begin{array}{l}\text { - Tidak bisa membaca kata-kata yang ada pada } \\
\text { soal dengan benar }\end{array}$ \\
\hline 2. & $\begin{array}{l}\text { Kesalahan } \\
\text { Memahami }\end{array}$ & $\begin{array}{l}\text { - Salah dalam menuliskan apa yang diketahui } \\
\text { dalam soal } \\
\text { - Sama dalam menuliskan apa yang diketahui dan } \\
\text { apa yang ditanyakan } \\
\text { - Salah dalam menyatakan permasalahan dalam } \\
\text { bentuk matematika } \\
\text { - Salah dalam memahami perintah dari apa yang } \\
\text { ditanyakan dalam soal } \\
\text { - Salah dalam memilih data yang digunakan } \\
\text { dalam soal } \\
\text { - Terlewatnya informasi yang penting }\end{array}$ \\
\hline 3. & $\begin{array}{l}\text { Kesalahan } \\
\text { Transformasi }\end{array}$ & $\begin{array}{l}\text { - Tidak mengubah informasi yang ada dalam soal } \\
\text { ke bentuk model matematika } \\
\text { - Ketidaktepatan mengubah informasi yang ada } \\
\text { dalam soal ke bentuk model matematika } \\
\text { - Sudah mengubah informasi yang ada dalam } \\
\text { soal tetapi tidak menuliskan keterangan dengan } \\
\text { tepat dan lengkap } \\
\text { - Salah dalam merencanakan solusi } \\
\text { - Tidak melanjutkan solusi pemecahan masalah } \\
\text { untuk menyelesaikan soal dengan baik }\end{array}$ \\
\hline 4. & $\begin{array}{l}\text { Kesalahan dalam } \\
\text { Keterampilan Proses }\end{array}$ & $\begin{array}{l}\text { - Salah dalam komputasi } \\
\text { - Tidak melanjutkan prosedur solusi pemecahan } \\
\text { masalah untuk menyelesaikan soal dengan baik } \\
\text { - Sudah melakukan komputasi dengan baik tetapi } \\
\text { terdapat kesalahan konsep }\end{array}$ \\
\hline
\end{tabular}




\begin{tabular}{ll}
\hline 5. Kesalahan Pada Notasi & - Ketidaktelitian pada proses perhitungan \\
& - Ketidaktepatan dalam menuliskan notasi \\
& - Tidak menulis satuan/variabel \\
& - Kesalahan dalam menggunakan satuan \\
&
\end{tabular}

\section{METODE}

Penelitian ini merupakan jenis penelitian deskriptif dengan pendekatan kualitatif. Penelitian deskriptif adalah penelitian untuk mengumpulkan informasi tentang status suatu gejala yang apa adanya pada saat penelitian dilakukan (Arikunto, 2007). Sedangkan penelitian kualitatif adalah penelitian yang digunakan untuk menganalisis dan mengidentifikasi fenomena yang terjadi, aktivitas sosial, sikap, presepsi, peristiwa, kepercayan secara individual maupun kelompok (Sugiyono, 2012).

Sampel pada penelitian ini adalah 3 orang peserta didik yang dipilih secara acak (Purposive Sampling) di kelas IX SMPIT Nurul Ilmi dengan menimbang kemampuan pemecahan masalah matematis peserta didik berkategori tinggi, sedang dan rendah yang telah dikategorikan sebelumnya oleh peneliti dengan cara subjek diberikan tes awal matematis yang kemudian dianalisis dengan menggunakan indikator pemecahan masalah dan diperoleh bahwa peserta didik dengan inisial S1 masuk kedalam kemampuan pemecahan masalah matematis berkategori tinggi, S2 berkategori sedang dan S3 berkategori rendah. Soal yang diberikan kepada peserta didik sebanyak 1 butir soal berbentuk uraian yang sudah diuji coba oleh peneliti sebelumnya yaitu Moh. Dulsalam (2015) dan sudah diuji kevalidan, reliabel, indeks kesukaran serta daya pembeda. Peneliti membagikan soal kepada sampel penelitian dan mereka menyelesaikan soal tersebut secara tertulis dikertas kemudian peneliti mengoreksi dan menganalisis hasil jawaban tertulis peserta didik berdasarkan indikator kesalahan pada teori Newman. Soal yang diberikan adalah sebagai berikut :

\section{SOAL}

Seorang anak bermain lompat-lompatan di halaman rumah. Langkah-langkah permainannya demikian : langkah 1 si anak melompat 1 lompatan ke depan kemudian menggambar garis sepanjang $1 \mathrm{~cm}$, langkah 2 kemudian si anak melompat 2 lompatan dari posisi terakhir ke kanan kemudian menggambar garis sepanjang $4 \mathrm{~cm}$, langkah 3 kemudian dia melompat 3 lompatan dari posisi terakhir ke belakang kemudian menggambar garis sepanjang $9 \mathrm{~cm}$, langkah 4 kemudian dia melompat 4 lompatan ke kiri kemudian menggambar garis sepanjang $16 \mathrm{~cm}$, langkah 5 demikianlah si anak mengulangi lompatannya ke depan dengan 5 lompatan dan menggambar garis sepanjang $25 \mathrm{~cm}$. Anak tersebut melompat berulang ke depan, ke kanan, ke belakang dan ke kiri. Jika diasumsikan arah ke depan dan ke belakang adalah sumbu y positif dan negatif, sementara arah ke kanan dan ke kiri adalah sumbu x positif dan negatif, dan posisi awal si anak adalah titik $\mathrm{O}(0,0)$ maka tunjukkanlah posisi si anak pada saat menggambar garis $1 \mathrm{~m}$ ! tunjukkanlah translasi pergerakan si anak tersebut ! 
Teknik analisis data yang digunakan pada penelitian ini adalah metode analisis kesalahan menurut teori Newman yang kemudian jawaban peserta didik yang menjadi sampel penelitian dianalisis dan dibagi menjadi ke dalam lima tipe kesalahan sesuai dengan indikator pada teori Newman.

\section{HASIL DAN PEMBAHASAN}

Berikut adalah hasil pengerjaan peserta didik dari 3 sampel yang telah diambil dengan purposive sampling :

\section{Hasil pengerjaan yang dilakukan oleh S1 yang termasuk dalam kategori tinggi.}
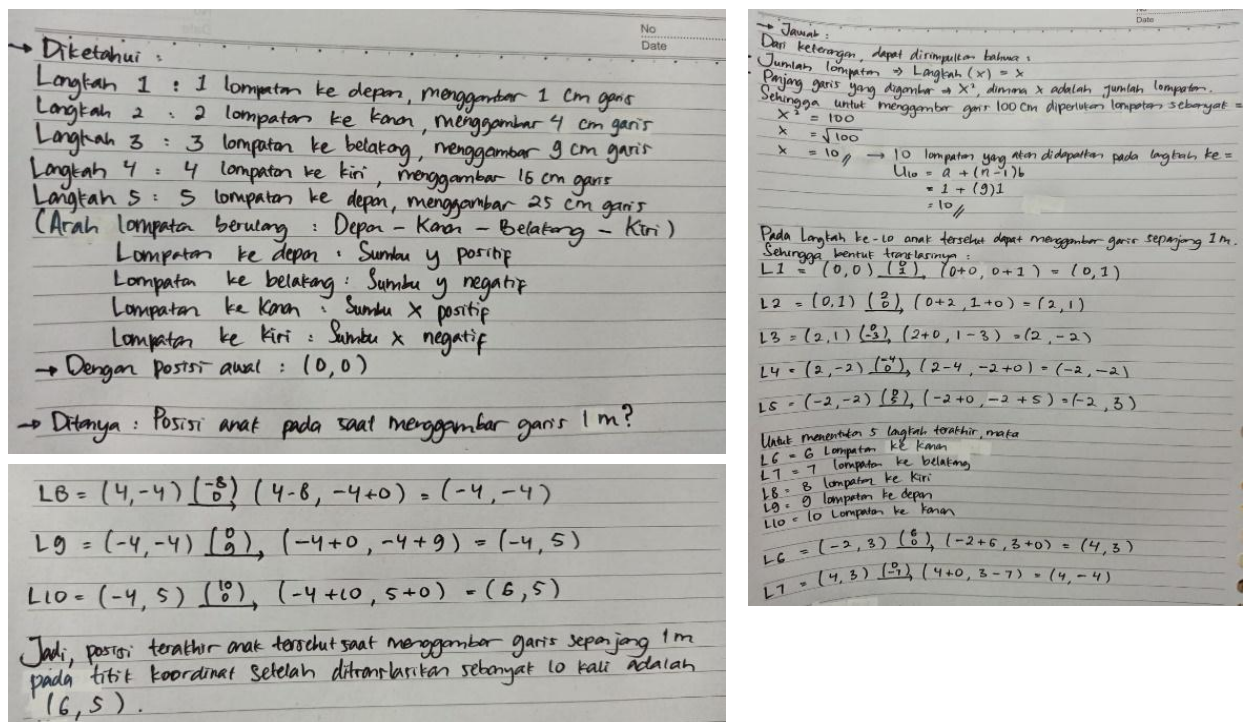

Gambar 1. Hasil Jawaban Peserta Didik S1

Terlihat pada gambar diatas bahwa peserta didik dengan inisial S1 benar dalam membaca kata-kata yang ada dalam soal, benar dalam menuliskan apa yang diketahui dalam soal, dapat membedakan informasi untuk menentukan mana yang diketahui dan ditanyakan, benar dalam menyatakan permasalahan ke bentuk matematika, benar dalam memahami perintah dari apa yang ditanyakan dalam soal, benar dalam memilih data yang digunakan dalam soal, dapat mengubah informasi yang ada dalam soal ke bentuk model matematika, tepat dalam mengubah informasi yang ada di soal ke bentuk model matematika, dapat mengubah informasi yang ada dalam soal dan menuliskan keterangan dengan tepat dan lengkap, benar dalam merencanakan solusi, melanjutkan solusi pemecahan masalah untuk menyelesaikan soal dengan baik, benar dalam komputasi, melanjutkan prosedur solusi pemecahan masalah untuk menyelesaikan soal dengan baik, sudah melakukan komputasi dengan baik dan tidak terdapat kesalahan konsep, teliti pada proses perhitungan, tepat dalam menuliskan notasi, menulis satuan/variabel dengan tepat, dan benar dalam memaknai jawaban. Hal ini berarti bahwa peserta didik dengan inisial S1 sudah dapat menyelesaikan soal tersebut dengan baik dan sempurna tanpa adanya kesalahan. 
2. Hasil pengerjaan yang dilakukan oleh S2 yang termasuk dalam kategori sedang.

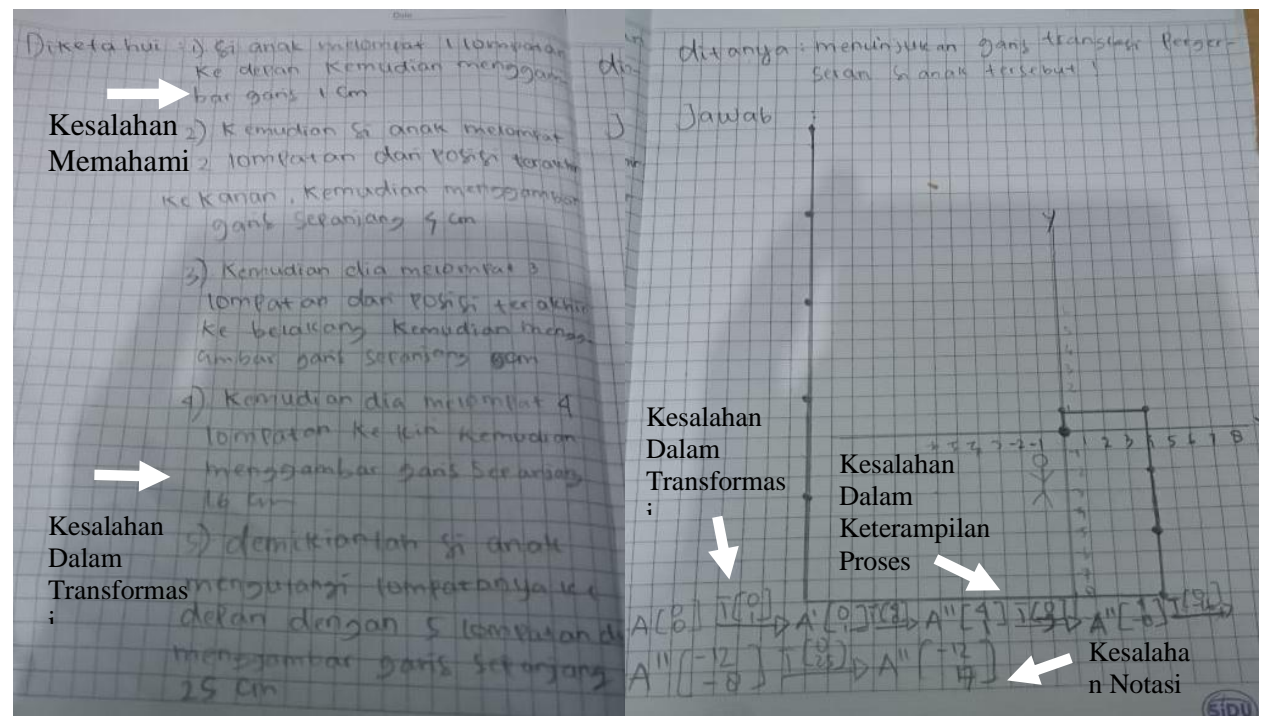

Gambar 2. Hasil Jawaban Peserta Didik S2

Untuk peserta didik dengan inisial S2 terdapat kesalahan sebesar $50 \%$ pada kesalahan memahami, 50\% pada kesalahan dalam transformasi, $60 \%$ kesalahan dalam keterampilan proses dan $60 \%$ kesalahan pada notasi. Pada kesalahan memahami, terlihat pada gambar diatas bahwa peserta didik dengan inisial S2 masih terdapat kekurangan dalam menuliskan apa yang diketahui dalam soal karna peserta didik belum menuliskan pengaruh tanda positif dan negatif pada arah yang diketahui. Selain itu S2 juga belum bisa memahami perintah dari apa yang ditanyakan dalam soal, masih belum bisa memilih data yang digunakan untuk menyelesaikan permasalahan dengan baik, dan masih melewatkan beberapa informasi yang penting dari dalam soal dikarenakan S2 hanya menuliskan informasi apa yang ada dalam soal tanpa mengetahui maksud dari informasi tersebut. Pada kesalahan dalam transformasi, peserta didik dengan inisial S2 belum tepat untuk mengubah informasi yang ada pada soal ke dalam bentuk model matematika, belum bisa menuliskan keterangan dengan tepat dan lengkap, salah dalam merencanakan solusi, dan tidak melanjutkan solusi pemecahan masalah dengan baik karena peserta didik hanya berhenti pada pergerakan langkah ke lima saja. Pada kesalahan dalam keterampilan proses, peserta didik dengan inisial S2 tidak melanjutkan prosedur solusi pemecahan masalah dengan baik, masih terdapat beberapa kesalahan konsep, dan ketidaktelitian dalam menghitung. Pada kesalahan notasi, peserta didik dengan inisial S2 tidak menuliskan notasi, tidak menulis satuan/variabel, dan tidak bisa memaknai jawaban dengan baik. Hal ini berarti bahwa peserta didik dengan inisial S2 belum bisa menyelesaikan soal tersebut dengan baik dengan presentase kesalahan sebesar $42 \%$.

3. Hasil pengerjaan yang dilakukan oleh S3 yang termasuk dalam kategori rendah 


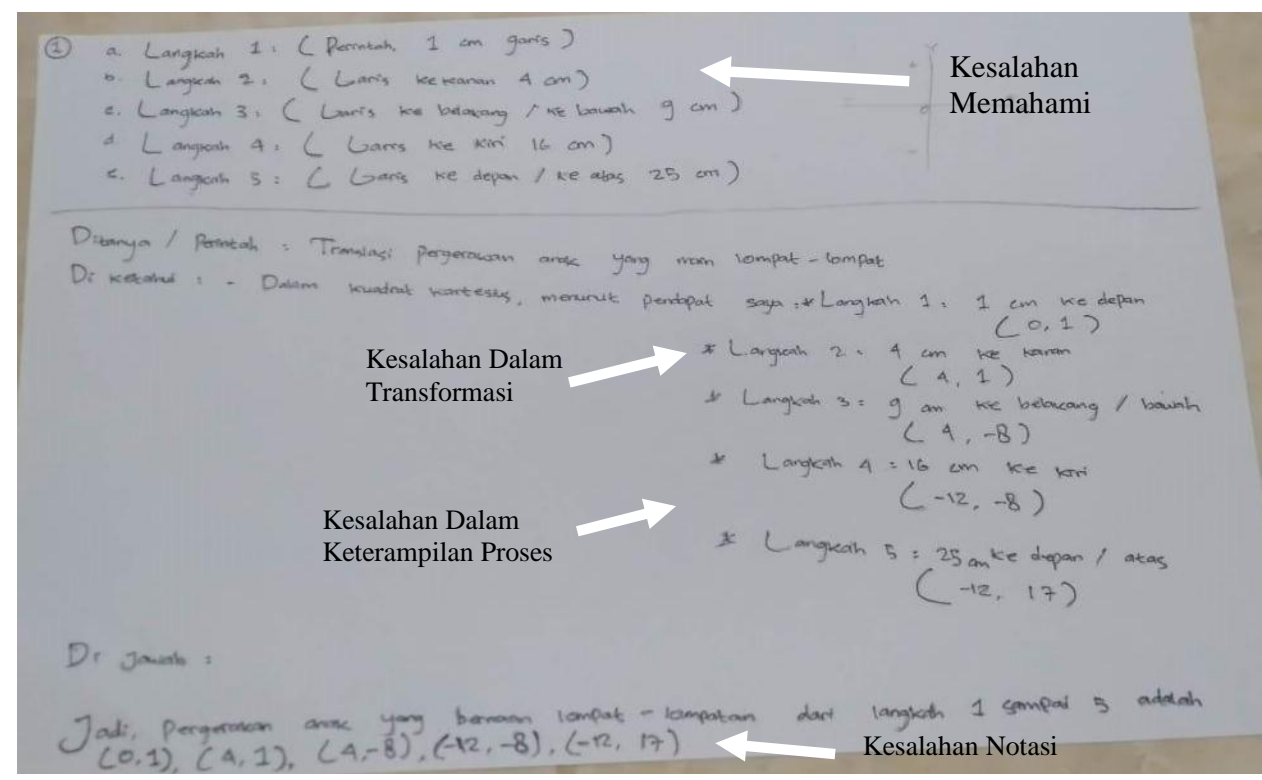

Gambar 3. Hasil Jawaban Peserta Didik S3

Untuk peserta didik dengan inisial S3 terdapat kesalahan sebesar $70 \%$ pada kesalahan memahami, $80 \%$ pada kesalahan dalam transformasi, $85 \%$ pada kesalahan dalam keterampilan proses, dan $80 \%$ kesalahan pada notasi. Pada kesalahan memahami, peserta didik dengan inisial S3 masih salah dalam menuliskan apa yang diketahui dalam soal karena peserta didik malah menuliskan titik koordinat dengan menggunakan angka pada panjang jarak satuan $\mathrm{cm}$, salah dalam menyatakan permasalahan dalam bentuk model matematika, tidak memahami perintah dari apa yang ditanyakan dalam soal, salah dalam memilih data yang digunakan dalam soal dan maish melewatkan beberapa informasi yang penting dalam soal. Pada kesalahan dalam transformasi, peserta didik dengan inisial S3 masih belum bisa mengubah informasi yang ada pada soal ke dalam bentuk model matematika, salah dalam merencanakan solusi dan tidak melanjutkan solusi pemecahan masalah untuk menyelesaikan soal dengan baik. Pada kesalahan dalam keterampilan proses, peserta didik dengan inisial S3 masih terdapat kesalahan dalam komputasi, tidak melanjutkan prosedur solusi pemecahan masalah untuk menyelesaikan soal dengan baik, terjadi kesalahan konsep dan terlihat bahwa peserta didik tidak teliti pada proses perhitungan. Pada kesalahan notasi, peserta didik dengan inisial S3 masih salah dalam menentukan notasi, salah dalam menggunakan satuan dan tidak bisa memaknai jawaban dengan baik. Hal ini berarti peserta didik dengan inisial S3 belum bisa menyelesaikan soal tersebut dengan baik dengan presentase kesalahan sebesar $63 \%$.

Berdasarkan hasil pengerjaan peserta didik diatas maka hasil analisis menurut Teori Newman dapat dilihat pada tabel berikut : 
Tabel 2. Kategori Tipe Kesalahan Peserta didik Menurut Teori Newman

\begin{tabular}{ccccc}
\hline Tipe Kesalahan & \multicolumn{3}{c}{ Peserta didik } & \multirow{2}{*}{ Total } \\
\cline { 2 - 3 } & S1 & S2 & S3 & \\
Kesalahan dalam Membaca & $0 \%$ & $0 \%$ & $0 \%$ & $0 \%$ \\
Kesalahan dalam Memahami & $0 \%$ & $50 \%$ & $70 \%$ & $40 \%$ \\
Kesalahan dalam Transformasi & $0 \%$ & $50 \%$ & $80 \%$ & $45 \%$ \\
Kesalahan dalam Keterampilan Proses & $0 \%$ & $60 \%$ & $85 \%$ & $48,3 \%$ \\
Kesalahan pada Notasi & $0 \%$ & $60 \%$ & $80 \%$ & $46,7 \%$ \\
TOTAL & $\mathbf{0 \%}$ & $\mathbf{4 2 \%}$ & $\mathbf{6 3 \%}$ & \\
\hline
\end{tabular}

\section{SIMPULAN DAN SARAN}

Berdasarkan hasil uraian diatas, kesalahan yang dialami peserta didik dalam menyelesaikan soal cerita yang diberikan sebagian besar terletak pada kesalahan dalam memahami soal yang diberikan, kesalahan dalam transformasi, kesalahan dalam keterampilan proses dan kesalahan pada notasi. Hasil dari penelitian diatas diperoleh 4 jenis kesalahan dan besarnya persentase untuk setiap kesalahan adalah $40 \%$ pada kesalahan memahami, $45 \%$ pada kesalahan dalam transformasi, $48,3 \%$ pada kesalahan dalam keterampilan proses dan 46,7\% pada kesalahan notasi. Hasil menunjukkan bahwa pada kesalahan dalam keterampilan proses terlihat dominan dibandingkan kesalahan yang lain. Secara umum, hal itu dikarenakan peserta didik masih belum bisa melanjutkan prosedur solusi pemecahan masalah untuk menyelesaikan soal dengan baik dan banyaknya ketidaktelitian peserta didik pada proses perhitungan.

Dari hasil penelitian diatas juga terdapat hubungan antara kemampuan pemecahan masalah matematis dengan kesalahan yang terlihat oleh peserta didik dalam menyelesaikan soal menurut teori Newman. Pada peserta didik yang memiliki kemampuan pemecahan masalah matematis berkategori rendah memiliki tingkat kesalahan yang lebih besar dibandingkan dengan peserta didik yang memiliki kemampuan pemecahan masalah matematis yang berkategori sedang maupun tinggi.

Untuk penelitian selanjutnya bisa dilakukan dengan memfokuskan pada aspek apa saja yang dapat mempengaruhi kemampuan pemecahan masalah peserta didik serta bagaimana cara menentukan solusi yang tepat untuk menyelesaikan soal dengan baik.

\section{DAFTAR RUJUKAN}

Arikunto, S. (2007). Manajemen Penelitian. PT Rhineka Cipta.

Dulsalam, M. (2015). Tugas Akhir Program Magister ( Tapm) Model Group Investigationdengan Pendekatan Humanistik Untuk Meningkatkan Program Pascasarjana. Universitas Terbuka Jakarta.

Karnasih, I. (2015). Analisis Kesalahan Newman pada Soal Cerita Matematis (Newman'S Error Analysis in Mathematical Word Problems). Jurnal Paradikma, 8(April), 37-51.

Layn, M. R., \& Kahar, M. S. (2017). Analisis Kesalahan Siswa Dalam Menyelesaikan Soal Cerita Matematika. Jurnal Math Educator Nusantara (JMEN), 03(02), 59-145.

Mahmudah, W. (2018). Analisis Kesalahan Siswa dalam Menyelesaikan Soal Matematika Bertipe HOTS Berdasar Teori Newman. Jurnal UJMC, 4(1), 
49-56.

Rahmania, L., \& Rahmawati, A. (2016). Analisis Kesalahan Siswa dalam Menyelesaikan Soal Cerita Persamaan Linier Satu Variabel. JMPM: Jurnal Matematika Dan Pendidikan Matematika, 1(2), 165. https://doi.org/10.26594/jmpm.v1i2.639

Sugiyono. (2012). Metode Penelitian Kuantitatif, Kualitatif, dan R\&D. Alfabeta. 